\title{
Function of Sere Bissu in the Past and Present in Ceremonies as the Character Education
}

\author{
Department of Dance, Universitas Negeri Makassar \\ Email: nurlina.syahrir@unm.ac.id
}

\begin{abstract}
The objective of this research is to reveal and to explain the development of Sere Bissu occurring estimatedly at the same time with atturioloang religion originating from lagaligo, i.e., prehistoric era. When Islam arrived and led in South Sulawesi religion in the beginning of 17th century, the role of bissu experienced degradation, because the process of Sere Bissu formation is always started from the behavior of bissu as a single authority. To prove the truth of this fact, a wide and comprehensive observation about Serre Bissu is needed, because it seems that the traditional ritual has absorbed various aspects of tis bacground. Therefore, historical, sociological, anthropological, and artistic approaches are needed to deal with the topic in order to explain and solve the problem.
\end{abstract}

Keyword: Sere Bissu - traditional rituals (ceremony) - character education.

\section{INTRODUCTION}

South Sulawesi region inhabited by four ethnic groups: Bugis, Makassar, Mandar, and Toraja. These ethnic groups are formed by the influencing of the historical background of social, cultural, and political from the kingdom-form govenment ruled there in the past. Since the early of 17 th century, especially in the rural areas, there is a belief of the unseen world which comes from pre- Islam religion. At least there are three small traditional communities that still retain their special existence amongs the majority of Muslim society. They are:

1. The community of Mappurondo believers in Polewali Mamasa district.

2. The community of Ammatoa believers in Bulukumba district.

3. The community of Tolotang believers in Sidrap districts

4. The community of Turioloang belivers in Pangkep districts.

The Bissu community which is centered in Segeri Mandalle village, Pangkajene island district as the Turioloang believers believe in what so-called god Seuwae (The God Almighty-Tuhan Yang Maha Esa). The Turioloang belief is belonged by the local communities and are inherited from generation to generation, lived and developed by later generations. This original culture inspired by the belief in one god almighty is based on the a cosmologic world view. Due to the current development of science and technology which has influence over the direction of modernization in all aspects of community life, in practice the old values will be pressed and displaced by the presence of new values.

A concept underlies the custom of Bugis Makassar communities can not be separated from their social strata. It was considered important to be used in the search for the background outlook on life, character, and attributes that refer to the communities. The four tribes mentioned above have been growing, maintaining, and developing their own traditions. In general, each of the groups (tribes) has specific cultural area, with the specific language and the specific of a particular culture system, so for a long period of time, their existence as an ethnic community can be survived. Nevertheless, in general it can be said that they have the same characteristics because of the intimate interactions among them.

Pangkep is the Bissu center today. The values occur in the community of Bone government have a pattern of its own, both in state ceremonies as well as in day-to-day social life. The social strata is divided into: nobles, freemen, and commoners. However, at this time, such a society does not exist anymore. It is because among the communities blend into each other so that it can no longer distinguish among the aristocratic strata and other societies. However, hereditary things can still boost the role of a person in the community view.A non-noble descendents who hold formal department will get appreciations from the community with the same respect which be given to the noble descendant, such as getting Puang Karaeng title. Besides those strata of society mentioned above, there is still a group of society with specific tasks. They are a group whose work to maintain and preserve arajang, called Bissu. Bissu are ordinary members of society, but have specific tasks. They live in a special house, which was at once the place of "government things" storage.

The Bissu group is led by someone called Puang matoa. The social roles and functions of Bissu are: (1) keepers, nurses, and arajang carrier, (2) ritual leaders, (3) sanro (shaman), (4) teacher for those who will get married. The customceremony performing which reflects the socio-cultural system related to cultural products, is implemented in a dance show called Sere Bissu. Before the entry of Islamic religion in South Sulawesi, Makassar Bugis people have known a dance called sere (lontara Galigo). Sacred rituals that survive up today is a traditional ceremony called 
Mappalili, which is one of the community customs conducted every year in Segeri mandalle village in Pangkep District. The Sere Bissu show in sacred ceremonies of Segeri mandalle society does not stand as an independent system, but as an integral part of the entire existing network and it is applied to the community who support the performance. The socio-cultural conditions of society life is changing so extensively. Althought it is adaptatif, the presence of Matoa Puang in the show could not be ruled out, although it is only as a mere complement but actually it is an essential part. Furthermore, the Bissu is considered as a mediator (shamman). The function of performing arts in people's lives can be grouped into three categories: (1) as a means of ceremony, (2) as an expression of personal feelings, and (3) as a spectacle [1]. Building on the function of the performing arts, Sere Bissu has the following functions:

1. As a means of ceremony, which Sere Bissu is used as part of Mapalili ceremony and other ceremonies.

2. As spectacles, which Sere Bissu presented in special events for the Bissu members.

In fact, the life of Sere Bissu today is indeed related to the place of that dance in the society. Its presence in the society is not only for spectacles, but also for other functions considered important in the life of its society. An important role of Sere Bissu in people's lives, causing them to live and develop in accordance with their time. One interesting phenomenon to uncover the journey of Sere Bissu, because this dance is made up of symbols and the symbolic behavior which later become one siginificance which is eligible to be shown. Such issues as mentioned above, have not been investigated by other researchers, because there is no scientific literature found that publish the results of research on the matter. So based on this fact, The researcher eagers to examine this matter. This study is expected to clarify some issues and answer some questions:

1. How Bissu Sere functions in the society

2. How is the performing formation of Sere Bissu

\section{LITERATURE REVIEW}

Sources are used and are selected to capture the data in this study. They are: (1) written sources; they are sources in the form of books, lontara, and articles published in newspapers or magazines, (2) oral sources; the verbal information obtained through interviews with informants. The important documentary sources used include:

1. Lontara 'Galigo' which was written during the reign of king Bone II, which is traslated by Andi Mappasissi in 1962. This book provides information about Bissu Bone and Bissu segeri bissu which includes an overview of sere bissu, the performance, and the function in the social life of that time.

2. Pappasang written in 1931 and found in Balla 'lompoa' musseums in Goa district, provides information about the position and duties of the bissu and the ritual behavior.

3. Lontara Sawerigading written during the reign of king Luwu in 1905, provides information about the community and itheir land.

4. The Bissu and the equipment, written by hamzah in 1978 to provide information about the equipment of image of the Bissu community and tools existed in the kingdom which become their responsibility.

5. Dance quest in Celebes written by Claire Holt in 1939, provides information about the shape of the Sere Bissu performance in Segeri Pangkep distric.

In addition to using data which derived from written sources such as the above, the data in the form of verbal information is also needed, to complete the written record or as the information comparison in the written sources. Verbal information obtained by interviews with the speakers. Given that Sere bissu live and thrive in the two districts, namely: Bone district and Pangkep district, the study tried to get information from this environment. In addition, data were also obtained by observation, namely: (1) direct observations conducted to obtain data that were more comprehensive and detailed, and more accurate, and (2) indirect observation, they were the observation of the photo or video.

\section{METHODS}

Many aspects determine the life of dances in societies. Art activities in the ritual life of the societies were important aspect in the life of dances. According to Heuser, sociological approach to art is to cover the whole field of art as a whole to face the problems of social dynamics. In this case Hauser questioned about the art symptoms and the symptoms of societies and the importance of realizing this in the study of art. In his book, Hauser explained that history consists of series of achievement made by individuals, who respond to certain situations within their capability [2].

Literally, it means the usefulness of social functions is something exists in the social life of the community. This research borrows the theory expressed by Radcliffe Brown, that function is the contribution of the activity of a part of the whole activity [3]. The understanding of Malinowski about the function in culture is all truly cultural activities aimed at satisfying a set of number of requirements relating to the human instinct of life [4]. From the above descriptions it is understood that the arts is as a result of cultural activities in the societies, its performance contributed for the benefit of society supporters. For people who culturally primitive, dances are expressions of the embodiment of social and religious rituals. Forms of ritual are still remains, but some lost their magical content. In addition, dance is a ceremony of love and submit to the power and natural events, such as prayer using the words to get the magical powers to protect its people. So, it is a form of reaction and interaction with the world [5]. All activities 
and journeys of human life that are considered important such as planting, harvesting, hunting, wars, birth, circumcisions, a girl's first menstruation, marriage, sickness, and death are always accompanied by the ritual dance as an integral part of the magic and religion [6]. Thus, a dance is part of a real life and it is functioning in life.

The embodiment of art in a traditional society with a variety of motifs and shapes clearly has meanings that blends with its surroundings. Therefore, discussions about art is always related to the scope of supporting community life and the socio-cultural dynamics of the supporting community as the background of its formation. From these descriptions when we examine more deeply, of course, has a continuing goal of an art appreciation, and from the prosess of its appreciation is expected to have a life value which can touch the deepest soul. In a special occasion, it can be interpreted as the main or primary finction. The religiomagical property in the Sere Bissu dance is a human trust to ghosts and the supernatural power to control things by means of religion if people can not overcome their anxiety by other means. This ceremony was conducted with the purpose of worshiping something that does not appear (the ruler of the gods of the universe, the spirit of ancestors, and non-human spiritual beings or what is considered God) in which a group of people dancing accompanied by the sounds to get magical powers to address more directly the problems of human life. Every major events such as avoiding crop failure, they make offerings on a simple table which is placed at the end of the land and many other major events in human life in order to be successful in all their activities. According to their thinking, the power is beyond the reach of the senses. Here they have embraced a belief that the universe is animated by all kinds of spirits by Sir Edward Tylor called animism [7]. The act of symbolism in the religious ceremony is a very important and it turns out people are always acting and doing something that symbolizes communication with God. It is because the God who creates and places them to the world. Thus, the symbolism in traditional societies not only bringing messages to do with religion, but also having order in the association among each other. From the description on the background, it can be seen that the Sere Bissu dance have a long life span and has a variety of functions. Thus, it is necessary to study the observations from the various approaches: the historical anthropological, sociological, and art. To express the position and function of the Sere Bissu dance in its society life, the approach used the historical anthropological and sociological in the hope that they can explain the functionality changes and their causes, and explain the relationship of the customs, mappalili and its relation to the position of the Sere Bissu in its society. The blending or the gathering of real elements and nonapparent elements that ultimately lead to the elements of trance (possesed) is the characteristic of Serre Bissu. It is interesting to analyze by the art approach. With the approach of various disciplines, it is expected to establish clarity that cover all aspects of the problems in this study.

\section{RESULTS AND DISCUSSION}

Bissu is common people but have specific privileges. Basically a bissu was like other men, but there was a change in him so that he did and acted as a woman. Even his voicewas also changed into a woman's voice. He dressed and acted as a woman. Bissu members lived in a house which is actually arajang palace. They are led by the oldest, most experienced and high expertise bissu. Not all men who have a trait like women can be a bissu. Those who do not become bissu were called calabai or Kawe-Kawe or in common terms are transsexual or transvestite. Under the leadership of Puang matoa and Puang lolo, the bissu led the Mappalili ceremony. According to the information from the bissu, they have no kinship with one another. However, because of having the equal tasks, they know each other and live in the same house in the arajang palace. To be a Bissu is not easy. A transvestite who is going to be a Bissu must have received 'the call' first from something unseen, in this case arajang. Once they felt they had received "the call", they reported the matter to Puang matoa or to Puang lolo. Once this was known by Puang matoa or Puang lolo, he was given specific guidance, either on his duties as a bissu or his obligations. This is done in the arajang palace in a certain ceremony full of sanctity, and only this community knows. The bissu is also divided into several groups: (1) the bissu tanre (height), (2) the bissu poncok (short), (3) The bissu core-core, (4) the host bissu, (5) kuneng lolo, and (6) The bissu lolo

In general, the duties and the obligations of the bissu are as follows:

1. The sustainers, the nurses, and the arajang carrier. Arajang today are currently only royal relics, were actually a symbol of power in the past, used by the kings. Those objects are requirements for all power and authority, in other words, it relates to the ownership of legitimate authority and standing symbols for the conduct rule, which serve as collateral 'legitimacy'. Therefore, only the bissu that can hold and as in charge to arajang.

2. The ritual leaders. Carrying out the rituals, specifically which are related to the ancestors, is also the task of the bissu. People believe that onlythe bissu who are able to communicate with their ancestors, and be the bridge between the 'powers above' with 'the underworld'. With the growing of islamic influence, this task is slowly fading. However, in certain ceremonies such as planting and harvesting rice ceremonies, the bissu's role as the leaders in the ritual is still be maintained in the traditional procedure.

3. Sanro (shaman). Curing diseases is also one of the bissu tasks, especially the treatment using spells.

4. Teachers for people who are getting married. Every marriage performed according to the procedure set by the customs, ranging from dating to determine the formation of new family.

The custom code of conducting new family requires each family member to comply with and stick to it and are 
responsible to maintain it, because they are holy norms [8]. The customs code of conducting new family include:

a. Manners in family life, either to the husband, inlaws, in-laws and other relatives of the husband.

b. Role in relation to the rights and obligations of married life.

c. Procedures in relationships between husband and wife.

If you do not understand the so-called custom, human would not be called human. Because the base of the customary is honesty, while strengthening your fear of the gods, coupled with a deep sense of shame. Being the very fear of the gods will make human apart from honesty (lontara Wajo). The origin of arajang or Kalompoang which has the divine quality and history, has been transforming a sacred power that gives the party the supremacy and ability to govern. As a mark of respect, the people provide the best piece of land which is the full right to Kalompoang and the owners. The land is named the butta Kalompoang that has two functions. First, as agricultural land which is reserved for the kingdom. Second, as the implementation of ritual ground before planting. This thing is a guarantee of legitimacy because it provides evidence that the holder has the power that comes from the power of the universe assigners.

In terms of preserving these sacred objects, the bissu with the authority of the divine power has established theirselves as the central control of public power, as well as priests who idolize the power of the divine. In terms of this relationship, The sosiety is always showing obedience, respect, and declared theirselves as the servants of the leader. As the owner of arajang, the bissu community make this thing as a legacy of generations, which slowly but surely, making them as a group that has the full authority in the community. From the cultural point of view, the fundamental things can be stated as follows. First, the leadership system like royal and non-royal people has been entrenched in Bugis Makassar society, as well as on the Pangkajene (Pangkep) society. Second, kinship system helped to shape the culture of the society in a broader sense, as it has become a tradition in social life. During the Sere bissu performance, few things have to avoid are:

1. It is abstinence for the quarrelling either in the family or with others, and when this happens, anything they expect will never come true.

2. It is abstinence when something passes in front of the area of the performance, and when it is violated, there would be a disaster such as droughts or floods that hit the area. It means that the people also will have trouble.

\section{The Transcendental Procession of Sere Bissu}

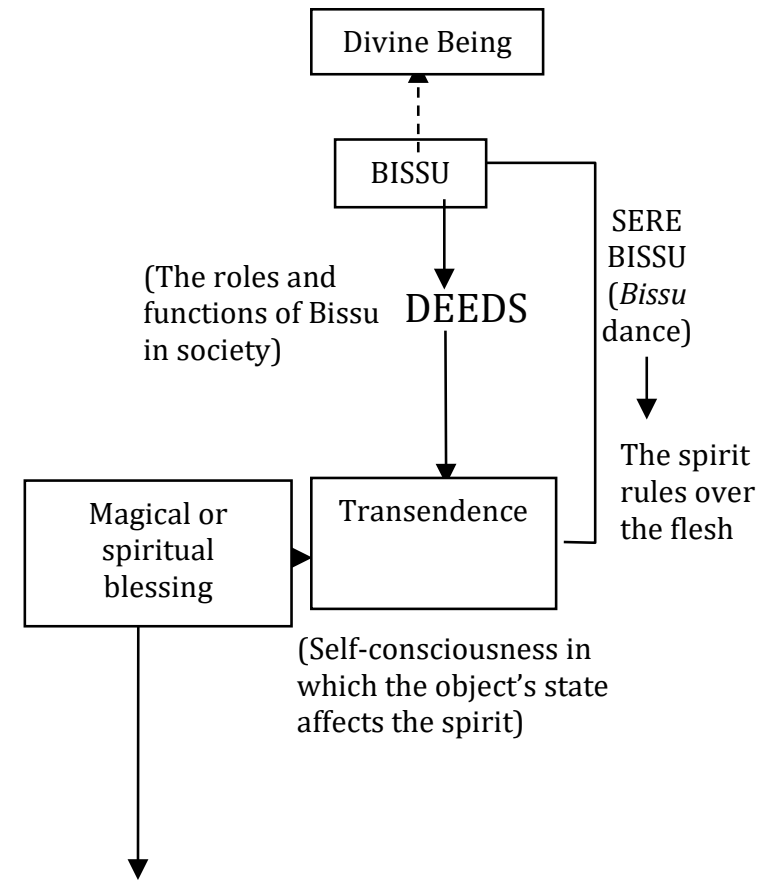

Prehistoric society relied on myths and legends to help themselves in understanding bizarre phenomena and thus produced symbols as their means of expression.

In addition to the above symbols, there is also a symbol in their movement. The bissu assumes that the movement they do is a form of a total surrender. They assume that the ancestral spirit that resides in the above-world, is represented by arajang (in this case the keris) they have. By offering everything on arajang, the value is equal to surrender to the gods who had been providing fertility and prosperity. The Sere bissu they do is to symbolize a devotion to the gods. In the description of Mapalili traditional ceremony, it is mentioned that all the movements and behavior done by the bissu based on their view of cosmology. They assume that in human it has elements of the Sumange (spirit). The Sumange is the core and is formed as customs that must be obeyed. To keep all His creation, the gods have formed an order in the form of customs, and His guards are the bissu, the bissu itself is the representation of the arajang. In their view, the representative and the represented are the same so that at any time the represented would incarnate into the representative. When they take decisions in certain situations, they always associates it with the previous events, because it is inherited and maintained by members of the society, and they believe that it is the will of their ancestors. Any actions taken tend to refer to the cultural value and the prevailing social system, in other words, the society is still consistent with the values of their traditional culture. 


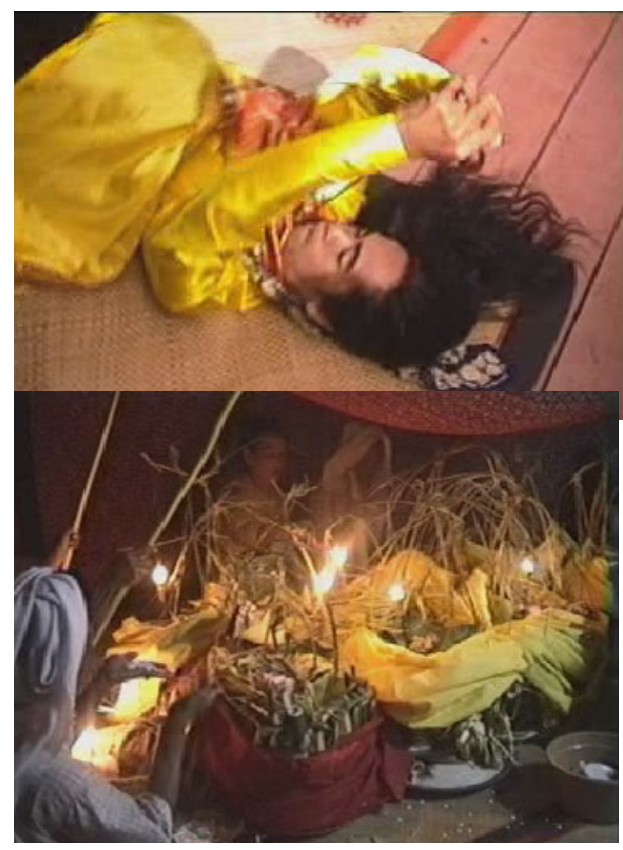

Fig. 1. Some expressions of the bissu, when they reach the transcendental, which is interpreted as a form of communication with the creator almighty, Puang Matoa was chanting mantras, documentation Nurlina, 2010

\section{CONCLUSION}

The performance of the Sere Bissu in the ceremony does not stand as an independent system, but an integral part of the entire existing network and it applies to the society that supports the performance. The socio-cultural conditions of life of the society changes so extensive, the sere bissu appears traditional dance genre which more adaptatif to Sthe environment. Furthermore, the Bissu considered a mediator (shaman). The Sere bissu has the following functions:

1. Means of ceremony, which the sere bissu used as parts of the Mapalili ceremony and other ceremonies.

2. Spectacle, which the sere bissu presented in a special event for the bissu.

The disclosure of the value of the Sere bissu which life in this society is a cultural foundation which establishes the behavior patterns of the past cumulatively. Later generations are this inherited socio-cultural patterns, which is seen as the idea of tradition. This idea that contains values that influence the supporting society, in this case the bissu. In fact, the life of the Sere bissu today is indeed associated with the position of that dance in the society. Its presence in the spciety is not only for the spectacle, but also for other functions which perceived as necessary in the life of the society. The important roles of the Sere bissu in people's lives causing it to remain live and develop in accordance with its time. Thus the author concludes that the changing of the Sere bissu's function is not something that happened suddenly. What has changed and what factors that influence it, will play together in a process of change. The Bissu itself deserves special attentions because they are still able to maintain its role in the social stability, in other words the Bissu could be used as the cultural legitimacy to the needs of social stability. In facing changes, the best attitude is overt and trying to be a subject in the process of changing. Closed and dissociate attitudes will harm the society culturally and it become useless. Human quality is the key to make tradition as something that is valuable and useful as part of the present or even the future.

\section{REFERENCES}

[1] Soedarsono, R. M. (1985). Peranan seni budaya dalam sejarah kehidupan manusia kontinuitas dan perubahannya. Universitas Gadjah Mada.

[2] Hauser, A. (2005). Social history of art, volume 4: naturalism, Impressionism, the film age. Routledge.

[3] Radcliffe-Brown, A. R. (1980). Struktur dan Fungsi Dalam Masyarakat Pri-mitif, terj. EE EvansPritchard dan Fred Eggan, Kuala Lumpur: Dewan Bahasa dan Pustaka.

[4] Koentjaraningrat (ed). (1980). Metode-Metode Penelitian Masyarakat, Gramedia, Jakarta

[5] Cummings, W. (2002). Making blood white: Historical transformations in early modern Makassar. University of Hawaii Press.

[6] Sachs, C. (1963). World History of the Dance: By Kurt Sachs. Norton.

[7] Haviland, W. A. (1985). Antropologi Jilid 2. edisi ke empat. Terjemahan oleh RG Soekardjo) Jakarta: Penerbit Erlangga Jakarta.

[8] Nyompa, Johan. (1997). Sistem Kekerabatan dan Pranata Kekeluargaan pada Masyarakat Orang Bugis di Sulawesi Selatan, FIIS-BUD Unhas, Ujung Pandang, p.42, p.51 